\title{
Conceptual metaphors in North African French-speaking news discourse about COVID-19
}

\author{
Hicham Lahlou*, Hajar Abdul Rahim \\ English Language Studies, School of Humanities, Universiti Sains Malaysia, 11800 USM Pulau Pinang, \\ Malaysia
}

\begin{tabular}{|c|c|c|}
\hline \multicolumn{3}{|l|}{$\begin{array}{l}\text { Conceptual metaphors have received } \\
\text { diseases in recent years. Most studies } \\
\text { discourse about disease. Similarly, a } \\
\text { coronavirus, i.e., COVID-19, especia } \\
\text { languages. The present study, in contra } \\
\text { discourse in French-language newspap } \\
\text { COVID-19 discourse in these newspap } \\
\text { them, using a conceptual metaphor th } \\
\text { French-language newspapers, namely } \\
\text { Tunisie, published in Tunisia, formed } \\
\text { the most frequent framing of COVID } \\
\text { KILLER, respectively. }\end{array}$} \\
\hline \multicolumn{3}{|c|}{$\begin{array}{l}\text { ywords: Conceptualization; conceptual metaphor; cor } \\
\text { domain }\end{array}$} \\
\hline & & \\
\hline \multicolumn{3}{|c|}{$\begin{array}{l}\text { ceptual metaphors in North African French-speaking } \\
\text { Indonesian Journal of Applied Linguistics, 11(3), 589- } \\
11 \text { i3.35949 }\end{array}$} \\
\hline
\end{tabular}

\section{INTRODUCTION}

The World Health Organization (WHO) declared the COVID-19 pandemic on March 11th, 2020 (World Health Organization [WHO], 2020). This declaration was the outcome of the concern about the alarming levels of the virus spread and severity and inactivity in fighting the virus. On March 11th, 2019, WHO reported over 118, 000 COVID-19 cases in 114 countries and 4,291 deaths (WHO, 2020). As Tedros Adhanom Ghebreyesus, DirectorGeneral of WHO, asserted, the pandemic will affect public health and all other sectors, calling everybody to take part in preventing the crisis (WHO, 2020). To date, the epidemic has affected all aspects of life worldwide, from health to livelihood, forcing the global community to adapt and learn different ways to continue with life, education, communication, economy, and labour. In relation to this, the media has been crucial in shaping the global community's understanding of everything related to COVID-19. The onslaught of COVID-19 news from early 2020 in various forms of media (printed, non-printed, social platforms, etc.) has received the attention of researchers in linguistics, and to date, COVID-19 pandemic language has been analysed from various aspects.

Most studies, however, have only looked at the conceptualization of COVID-19 news discourse in English. Few researchers have investigated how it is conceptualized in French-language media discourse, particularly in Africa, which has the highest number of daily French speakers worldwide. There are currently 300 million French speakers worldwide. Europe accounts for $33.4 \%$, sub-Saharan Africa and the Indian Ocean for $44.4 \%$, North Africa and the Near East for $14.9 \%$, America and the Caribbean for $7 \%$, Asia and Oceania for $0.3 \%$ (International Organisation of La Francophonie,

\footnotetext{
* Corresponding Author

Email: hlahlou2003@hotmail.com
} 
2019). As a result, research into how these nations' news discourse conceptualizes the novel coronavirus is required. The authors believe that this is the first study to offer a deep insight into how the media in Morocco and Tunisia, which have the highest percentages of French speakers in Maghreb (North Africa), $35 \%$ and $52 \%$, respectively (International Organisation of La Francophonie, 2019), conceptualizes disease.

Furthermore, the current study investigated how COVID-19 is framed in French and conceptualized in Moroccan and Tunisian news discourse, employing conceptual metaphor. According to Kövecses (2018), conceptual metaphors form the language of the media. Therefore, the study of how things are conceptualized in the media requires metaphorical conceptualization. The metaphorical mappings identified are compared with the Master Metaphor List (Lakoff et al., 1991), which serves as the foundation for conceptual metaphor categorization in English (Mason, 2004). By identifying the conceptual metaphors used in North African Frenchspeaking news discourse, the present study's findings add to the existing research on how disease is conceptualized in other languages than English and hence on language universals and particularities.

The current study is thus an analysis of the conceptual metaphors used in COVID-19 discourse in French-language newspapers published in North African French-speaking countries, namely Morocco and Tunisia. The study focused on the use of conceptual metaphors in COVID-19 discourse during the three months following WHO's declaration of COVID-19 as a pandemic. Therefore, the period of the study begins in the middle of March 2020, when the international community began to take COVID-19 seriously, and countries went into lockdown, until the middle of June 2020, when many countries lifted partial/complete lockdown orders.

\section{Conceptual Metaphors}

The meaning that a person wishes to communicate during a discourse may either be derived directly from the target domain, i.e., literal meaning or from a source domain, that is, routinely correlated with the target, i.e., metaphorical meaning (Kövecses, 2018). Metaphor is the basic mechanism by which individuals grasp abstract ideas and perform abstract reasoning (Lakoff, 1993). In other words, metaphor is crucial in verbal communication as it enables humans to describe and think about more abstract concepts in relation to more physical and concrete concepts (e.g., Kövecses, 2010, 2015; Lahlou, 2020, 2021; Lakoff \& Johnson, 2008;). Metaphor helps people living with illness to communicate their experiences to themselves and to others. In paucity of expressions to effectively express bodily emotions, metaphor helps individuals render unknown physical sensations such as pain more tangible (Lupton, 2012; Van der Geest \& Whyte, 1989).

A conceptual domain from which humans draw metaphorical expressions to comprehend another conceptual domain is the source domain. Typically, this domain of experience is more concrete or tangible, more directly experienced, and better understood. The target domain, on the other hand, which is generally more abstract, less directly experienced, and less understood, is the conceptual domain that is understood via the source domain and metaphor (Kövecses, 2010, 2015). A metaphor is a set of mappings between the components of two mental frames. For instance, a traveller's life is a journey, and so is the life of a person leading a life. Mappings between the way of travelling and living, a traveller's destination and an individual's life goals, and the way physical obstacles and life difficulties are produced build the conceptual metaphor LIFE IS A JOURNEY (Kövecses, 2015).

The conceptual metaphor of journey is also common in expressing love relationships. Everyday English expressions such as 'We're at a crossroads', 'I don't think this relationship is going anywhere' and 'Our marriage is on the rocks', to use Lakoff and Johnson's (2008) examples, demonstrate how Journeys (source domain) are metaphorically mapped onto love (target domain). What Lakoff and Johnson (2008) termed conceptual metaphor makes up such mapping. The JOURNEY domain mappings give rise to a specific conception of love in relation to JOURNEY. LOVE IS A JOURNEY is a metaphor since it constitutes a conventional association of a domain with another. It is conceptual because the motivation for metaphor takes place at the conceptual level (Lakoff \& Jonson, 2008). At a deeper level, a conceptual metaphor occurs, linking two otherwise unrelated semantic domains. The linguistic or surface metaphors, on the other hand, are the realisations of the conceptual metaphor (Charteris-Black, 2004; Lakoff \& Johnson, 2008). The metaphorical expressions 'We're at a crossroads', 'I don't think this relationship is going anywhere' and 'Our marriage is on the rocks' are only linguistic realizations of conceptual metaphors (Lakoff \& Johnson, 2008). Conceptual metaphor structures individuals' understanding. Metaphor source domains are based on humans' bodily and sensorymotor experience that develops into the source of conceptualization and reasoning (Johnson, 2008).

Metaphors are ubiquitous since they rely on basic and commonly shared schematic knowledge that effectively constructs the capacity of people to reason and interact about several diverse kinds of situations. They reliably communicate an alarming, negatively valenced tone that captures attention and provokes action (Flusberg et al., 2018). They are 
powerful when the source domain brings to mind a salient structure (or emotion), when knowledge of the structure of a source domain, or its emotional connotation, is well known to the linguistic group speakers, and when the comparison between the target domain and the source domain of a particular culture is acceptable (e.g., Flusberg et al., 2018; Kövecses, 2005; Lakoff, 2008 ).

There has been a consensus among linguists in the literature that diseases and viruses are typically described and interpreted in terms of war metaphors (e.g., Flusberg et al., 2018; Harrington, 2012; Sontag, 1978; Wicke \& Bolognesi, 2020). War metaphor is not a new linguistic phenomenon. The representation of illness as an attacker armed with a spear or quiver dates to the Middle Ages (Montgomery, 1991, cited in Lupton, 2012). Indeed, war metaphors have been found in political campaigns, battling with cancer, wars against crime, poverty, and even salad (Flusberg et al., 2018). For instance, Karlberg and Buell (2005) found that $17 \%$ of articles in Time Magazine and $15 \%$ of articles in Newsweek between 1981 and 2000 comprised at least one war metaphor. In contemporary medical and public-health discourses dealing with cancer, infectious diseases and other illnesses such as HIV/AIDS, the language of warfare is highly prevalent (Lupton, 2012).

Humans experience war in everyday life from history books and newspapers to television. War metaphors captivate humans' attention, generate emotional reactions, utilize a plentiful source of schematic knowledge, and direct people to construct certain views on a myriad of issues (Flusberg et al., 2018). War metaphors trigger a sense of fear, which in turn induces people to pay attention, change their opinions, and respond to central issues like illnesses (Flusberg et al., 2018). War metaphors are so familiar that they are also found in doctor-patient discourse. According to Reisfield and Wilson (2004), there are several reasons doctors and patients often use the metaphor of war in their discourse. First, war metaphor is omnipresent in one's culture (e.g., wars on drugs, crime, and illiteracy). Second, it can easily apply to serious diseases such as cancer, where there seems to be an ideal metaphorical correspondence: an enemy (a disease/cancer), a commander (a doctor), a fighter (a patient), allies (a health team), and formidable arms (including chemical, biological, and nuclear weapons). Third, an unmistakable seriousness of intent is connoted. Finally, the focusing quality of war is extraordinarily high, and its images of force and violence serve as powerful counterpoints to the helplessness and passivity frequently associated with serious illness.

The discourse about the novel Coronavirus (COVID-19) pandemic employs war metaphors in public discourse, the media, and even in the tweets by laypeople. Wicke and Bolognesi (2020), for example, investigated how Coronavirus is conceptualized on Twitter during the period between March and April 2020. They found that the FAMILY literal frame, or domain, covers a larger part of the corpus, followed by the metaphorical frames of which WAR, among MONSTER, STORM and TSUNAMI, was the most common, and so possibly the most conventional one. Interestingly, the results confirmed not only the omnipresence of the WAR frame in the pandemic discourse but also showed that this frame is employed to speak about certain characteristics of the pandemic, such as its diagnostics and treatment. Other studies, on the other hand, have challenged the use of war metaphors in the present epidemic, claiming that it ignores significant factors like mutual care or empathy, leading to breakdowns in social behaviour and the democratic system (e.g., Sabucedo et al., 2020).

Most literature on conceptual metaphors focuses on metaphors in English, with only minimal reports on other languages (Sardinha, 2011). Research into metaphors in other languages is necessary to broaden the understanding of linguistic, as well as conceptual, metaphors and to determine how similar and/or different they are. The new Coronavirus, or COVID-19, is a case in point. Despite widespread interest in how viruses and diseases are perceived, research on how people conceptualize COVID-19 and the conceptual metaphors they employ when talking about and discussing it remains limited across languages. The current study sought to analyse conceptual metaphors used in COVID-19 discourse in Frenchlanguage newspapers in order to achieve this goal. The research explores how COVID-19 is framed in the French language and conceptualized in Moroccan and Tunisian news discourse.

\section{METHOD}

The present study is a descriptive qualitative study based on the Conceptual Metaphor Theory (CMT) framework, which employed corpus linguistics as a support method. Two North African Frenchlanguage newspapers were selected as the source of data for the current study:

1. Libération (https://www.libe.ma/), a daily French-language Moroccan newspaper.

2. La Presse de Tunisie (https://www. https://lapresse.tn/), a daily Frenchlanguage Tunisian newspaper.

These newspapers were chosen not just because they are the most widely circulated, but also because they are print newspapers with free online access. Furthermore, these were the only newspapers with issues from the months under study available on their websites. For the purpose of the study, texts collected to create the corpus of the 
study include all the issues, as well as articles, of the two newspapers published from March 25th 2020 until June 15th 2020, the period from the initiation of lockdown orders around the world to mitigate the virus transmission until partial/complete lifting of lockdown were implemented. Archives for all the newspapers mentioned above are freely accessible from their websites. The authors' original intention was to examine the newspaper's issues starting from 12 March, immediately after WHO's declaration of COVID-19 as a pandemic. However, the newspapers' issues available on the newspapers' websites are from 25 March 2020 onwards. The corpus of the two newspapers published over the roughly three-month period consists of $3,388,781$ words. The breakdown of the tokens is shown in Table 1.

Table 1

\begin{tabular}{lc} 
Newspaper Corpus \\
\hline \multicolumn{1}{c}{ Newspaper Corpus } & Word Tokens \\
\hline Libération & $1,790,614$ \\
La Presse de Tunisie & $1,598,167$ \\
Total & $\mathbf{3 , 3 8 8 , 7 8 1}$ \\
\hline
\end{tabular}

There are two forms of corpus-based metaphor analysis: entire corpora, in which all metaphors are manually coded and retrieved in advance, and concordance-based research, in which only concordances comprising of search words occurrence are studied. Entire corpus analyses, unlike concordance-based analyses, are influenced by the amount of data that must be coded. A concordance-based analysis is often performed on a sample of concordance lines extracted from the corpus (e.g., 1,000 lines). The choice of search terms influences concordance-based analyses because they specify what will and will not be found in the corpus (Sardinha, 2011). The current research is a qualitative study that adopts a concordancebased analysis for several reasons. First, like other newspapers, the selected newspapers cover a wide range of topics, including politics, economy, society, culture, and sports, and COVID-19 is not mentioned in most newspapers columns. Second, concordance helps identify linguistic metaphors (or metaphorical expressions) in a corpus. It lists the search word or node word in its context. However, in longer texts, the search word will be examined by checking sentences before and after the concordance line to get a more exhaustive data set on the metaphorical expressions used. This is only possible if longer sections of text are read (Koller, 2006). In addition, in the current study, the concordancebased analysis is carried out on all concordance lines extracted from the corpus rather than a sample of the concordance lines.

The newspaper data were downloaded electronically from the newspapers' websites and converted to plain text using AntFileConverter (1.2.1). The AntConc 3.5.8 corpus analysis software (Anthony, 2005) was employed to generate data for analysis. This analysis software fulfils several functions, such as Concordance, File View, Word List, and Collocates. The current study mainly used Concordance and File View. Via AntConc 3.5.8, it is easy to switch between Concordance and File View. The search for concordance of the node word COVID-19 in Libération corpus, for example, resulted in a list of 2325 concordance lines as seen in Figure 1.

\section{Figure 1}

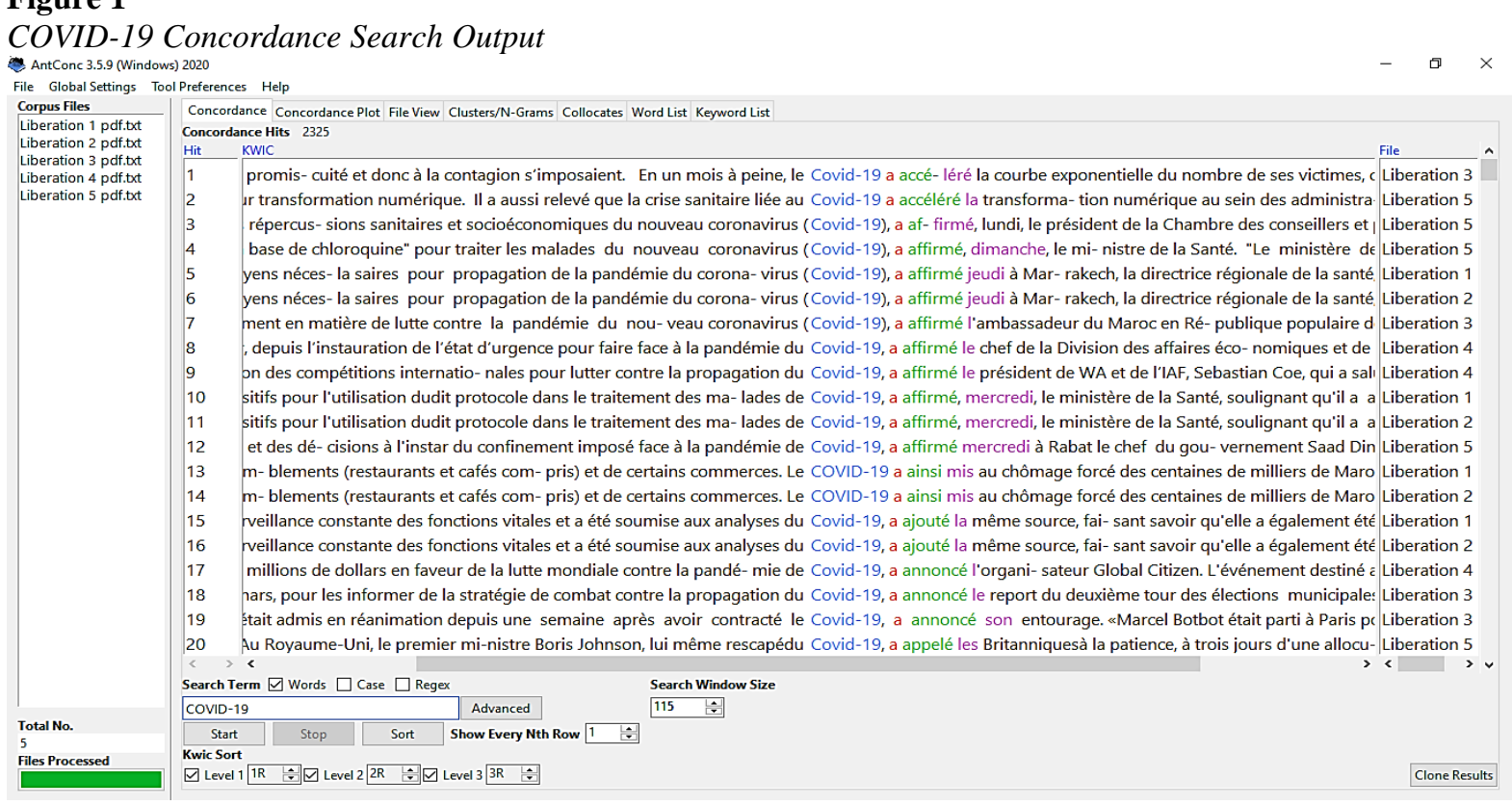


Clicking the node word COVID-19 in the first concordance in the figure above, AntConc automatically jumps to the File View, showing the entire context where COVID-19 is used as shown in Figure 2.

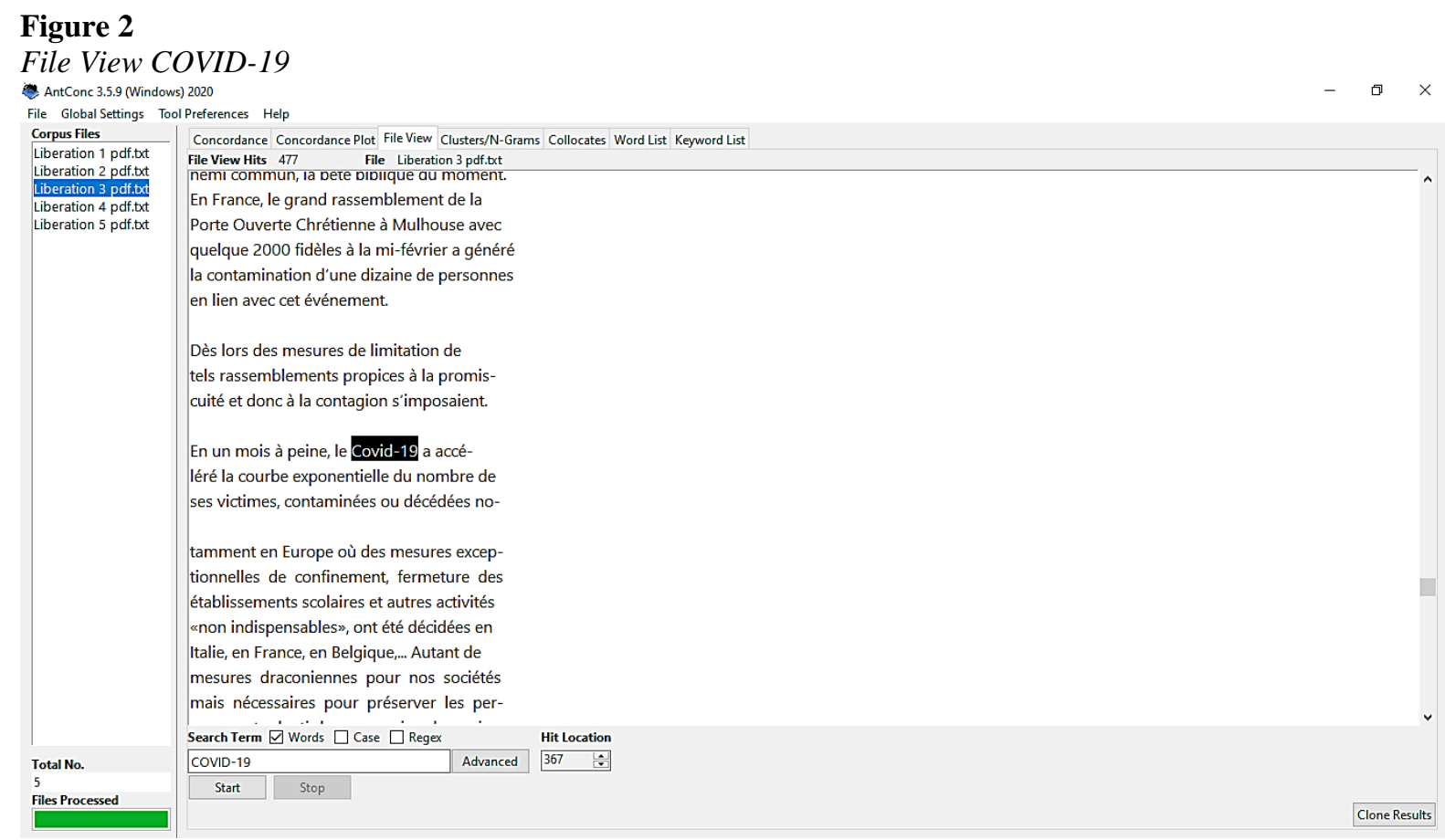

The authors searched the concordance lines for the different search words referring to COVID-19 in French one by one. In other words, the concordance hits for the target words Covid-19 (COVID-19), Coronavirus (Coronavirus), virus (virus), épidémique (epidemic), and pandémique (pandemic) were investigated. In the absence of a precise automatic metaphor identification, the concordance lines generated were analysed manually, and for accuracy, linguistic metaphors were manually identified (Sardinha, 2008). A linguistic metaphor is an expression that comprises at least one metaphorically used term, suggesting that it was employed to indicate a domain that is incongruent with the surrounding context (Cameron, 2003). In other words, a linguistic metaphor needs to consist of a vehicle term, incongruous to the surrounding context or the meaning derived from the co-text. Furthermore, this congruity can be resolved by some 'transfer of meaning' from the vehicle term (source domain) to the topic (target domain). The meaning of the vehicle should be different from its basic meaning (Cameron, 2003, 2008).

According to cognitive metaphor theory (CMT), "conceptual metaphors are static, fixed mappings between Topic (or target) and Vehicle (or source) domains" (Cameron, 2008, p. 46). For example, in the corpus citation: ...the pandemic is hitting Haitian workers hard..., the metaphorical vehicle of the pandemic (the topic or target domain) is hitting. In this example, pandemic (Topic) is described in terms of an enemy that attacks
(Vehicle) . Thus, in the present study, the node words, e.g., épidémique (epidemic), and their relation with collocates that seem incongruous were examined with recourse to context, i.e., concordance lines, to determine their metaphoricity. It is worth mentioning here that in the current study, following Metaphor Identification Procedure (MIP), metaphor is considered in its broader sense, including metaphor, simile, metonymy and personification (Sun \& Li, 2016).

As mentioned before, linguistic metaphors or metaphoric expressions are realizations of conceptual metaphors (Lakoff \& Johnson, 2008). Following the identification of linguistic metaphors, they were classified based on the conceptual metaphors that underlie and motivate them. The metaphorical mappings that were used were adopted from the Master Metaphor List (Lakoff et al., 1991). The list serves as the foundation for the categorization of conceptual metaphors identified given that it is made up of manually validated metaphors that are prevalent in English (Mason, 2004). It should be noted that the citation examples, consisting of linguistic metaphors, used in the discussion of the study results were translated by the author and verified by two French-English language experts.

\section{FINDINGS AND DISCUSSION}

The analysis of how COVID-19 is conceptualized in the French-language newspapers: Libération, and La 
Presse de Tunisie, showed the prevalence of conceptual metaphor in conceptualizing Covid-19. This concurs with other studies which have shown that conceptual metaphor forms media's language. This is because, as mentioned earlier, conceptual metaphor is essential in the communication of human beings as it allows them to understand abstract concepts in terms of concrete concepts (e.g., Lakoff \& Johnson, 2008; Kövecses, 2010, 2015). The data obtained from the newspaper data set showed a diversity of metaphorical mappings to express COVID-19-related ideas. The most prototypical framing of COVID-19 identified was in terms of WAR, followed by DISASTER. A less prototypical conceptualization of the virus was in terms of KILLER.

The selected newspapers' conceptualizing of COVID-19 as WAR was manifested in various metaphorical mappings to convey illness, treatment, and medicine. More particularly, the data retrieved from the newspapers under investigation exhibited various subcases of TREATING ILLNESS IS FIGHTING A WAR, namely THE DISEASE IS AN ENEMY, THE BODY IS A BATTLEGROUND, INFECTION IS AN ATTACK BY THE DISEASE, MEDICINE IS A WEAPON, MEDICAL PROCEDURES ARE ATTACKS BY THE PATIENT, WINNING THE WAR IS BEING CURED OF THE DISEASE, and BEING DEFEATED IS DYING.

\section{The Disease is an Enemy}

Visualizing the disease as an enemy is commonplace in all the newspapers under investigation, being associated with military elements like threat, combat, and defence. Table 2 shows examples of concordance lines in which Coronavirus is conceptualized as an enemy.

Table 2

Conceptual Metaphor - THE DISEASE IS AN ENEMY

\begin{tabular}{|c|c|c|c|}
\hline Conceptual & & Examples & English Translation \\
\hline \multirow{2}{*}{$\begin{array}{l}\text { THE DISEASE IS } \\
\text { AN ENEMY }\end{array}$} & (1) & \begin{tabular}{lllll}
..les autorités & \multicolumn{2}{c}{ marocaines } & ont pris \\
graduellement des & mesures pour & enrayer la \\
propagation de & cet ennemi & invisible. \\
(Libération)
\end{tabular} & $\begin{array}{l}\text {...Moroccan authorities have gradually taken } \\
\text { steps to halt the spread of this invisible enemy. }\end{array}$ \\
\hline & (2) & $\begin{array}{l}\text { Pour contrer les effets néfastes de cet ennemi } \\
\text { redoutable que constitue le coronavirus... ( } L a \\
\text { Presse de Tunisie) }\end{array}$ & $\begin{array}{l}\text { To fend off the harmful effects of this dreadful } \\
\text { enemy that constitutes coronavirus... }\end{array}$ \\
\hline
\end{tabular}

It is worthy of note that, in example (2) above, the enemy's nature is different from the common warfare connotation. It is not a noticeable or camouflage dressed soldier. It is an enemy that is not visible to the naked eye. The enemy is more associated with an alien or evil in this sense.

\section{The Body is a Battleground}

The virus invades and penetrates a humans' body through the nose, mouth, and eyes. It starts then attacking and killing the cells in the lungs. It is the immunity of the human's body that fights off this attacker. The infection's attack and immunity's defence correspond with a country's defence against another country's armed attack. The instances in Table 3 portray the activation and ability of the immune system to fight off the virus within the body.

Table 3

Conceptual Metaphor - THE BODY IS A BATTLEGROUND

\begin{tabular}{|c|c|c|}
\hline Conceptual & Examples & English Translation \\
\hline THE Body Is A & $\begin{array}{l}\text { (1) ...les scientifiques espèrent qu'un patient } \\
\text { contaminé soit immunisé contre le nouveau } \\
\text { coronavirus au moins pendant quelques } \\
\text { mois. (Libération) }\end{array}$ & $\begin{array}{l}\text {... Scientists hope that an infected patient will } \\
\text { be immune to the new coronavirus for at least } \\
\text { a few months. }\end{array}$ \\
\hline BATTLEGROUND & $\begin{array}{l}\text { (2) ...des médicaments agissant sur le système } \\
\text { immunitaire, pour contrôler la réaction } \\
\text { inflammatoire de l'organisme. (La Presse } \\
\text { de Tunisie) }\end{array}$ & $\begin{array}{l}\text {...drugs acting on the immune system to } \\
\text { control the body's inflammatory reaction. }\end{array}$ \\
\hline
\end{tabular}

\section{Infection is an Attack by the Disease}

As mentioned in the previous subsection, COVID19 is conceptualized as an invader that penetrates the human body, which constitutes the battlefield. The mapping of the source domain of ARMY (as in war) on INFECTION is ubiquitous in the newspapers under study. In the examples in Table 4, COVID-19 does not only hit individuals, but it also attacks countries worldwide. It even beats a human's body and mind, as shown in Example (2) below. 
Table 4

Conceptual Metaphor - INFECTION IS AN ATTACK BY THE DISEASE

Conceptual

Examples

English Translation

Metaphor

(1) Aux Etats-Unis, la pandémie frappe de plein fouet In the United States, the pandemic is hitting les ouvriers haitiens de la filière avicole... Haitian workers hard in the poultry industry...

INFECTION IS

AN ATtack BY

THE DiSEASE (Libération)

(2) Un excès de méfiance envers ce nouveau An excess of suspicion of this new coronavirus qui ronge le corps et l'esprit. ( $\mathrm{La}$ coronavirus which wears body and mind Presse de Tunisie) down.

\section{Medicine is a Weapon}

The immune system preserves their health and protects their body from invasion by microorganisms that cause disease. An individual's administration of a vaccine prepares their immune system to combat the infection, by activating the immune system to detect the disease and prevent it from future infection. Thus, a vaccine, as well as medicine, are understood in terms of a weapon to combat COVID-19, as shown in the examples in Table 5 .

Table 5

Conceptual Metaphor - MEDICINE IS A WEAPON

\begin{tabular}{|c|c|c|c|}
\hline Conceptual & & Examples & English Translation \\
\hline MED & (1) & $\begin{array}{l}\text {..l'hydroxychloroquine...un antibiotique, } \\
\text { constitue l'arme fatale pour inhiber le virus... } \\
\text { (Libération) }\end{array}$ & $\begin{array}{l}\text {...the hydroxychloroquine .... an antibiotic, is } \\
\text { the lethal weapon to inhibit the virus... }\end{array}$ \\
\hline WEAPON & (2) & $\begin{array}{l}\text {...approches sont testées contre le coronavirus: } \\
\text { des antiviraux pour combattre directement le } \\
\text { virus... (La Presse de Tunisie) }\end{array}$ & $\begin{array}{l}\text {...approaches are being tested against the } \\
\text { coronavirus: antivirals to directly fight the } \\
\text { virus... }\end{array}$ \\
\hline
\end{tabular}

Nevertheless, in the current absence of a medicine or vaccine to beat COVID-19, some alternative strategies were adopted to halt the spread of the virus. One of the most powerful weapons was social distancing. This was characterized by instructions like Restez à la maison (Stay at home), as in "...le plus important est de rester à la maison pour empêcher la transmission du virus." (Libération) (...the most important thing is to stay at home to prevent the transmission of the virus), and "La plupart d'entre nous suivons la consigne de rester à la maison..." (La Presse de Tunisie) (Most of us follow the instruction to stay at home...). Another powerful weapon to stop Coronavirus was hygiene, as in "...pour encourager la distance sociale et les règles d'hygiène, comme se laver régulièrement les mains." (Libération) (...to encourage social distancing and hygiene rules, such as washing your hands regularly."

\section{Medical Procedures are Attacks by the Patient}

A small number of concordance lines exhibited this metaphor. There were few examples of linguistic metaphors representing this conceptual metaphor in Libération, compared with La Presse de Tunisie. As presented in Table 6 below, the medical scientist is optimistic about medical individuals' ability and performance in stopping COVID-19. The statement implies ardent hope, usually absent at the onset of a pandemic outbreak.

Table 6

Conceptual Metaphor - MEDICAL PROCEDURES ARE ATTACKS BY THE PATIENT

\begin{tabular}{|c|c|c|}
\hline Conceptual Metaphor & Examples & English Translation \\
\hline $\begin{array}{l}\text { MEDICAL PROCEDURES } \\
\text { ARE ATtaCKS By THE } \\
\text { PATIENT }\end{array}$ & $\begin{array}{l}\text { (1) “...cela prouve que nous pouvons bloquer le } \\
\text { virus", a dit le haut responsable scientifique... } \\
\text { (Libération) }\end{array}$ & $\begin{array}{l}\text { "...this proves that we can block the virus," } \\
\text { said the senior scientist... }\end{array}$ \\
\hline
\end{tabular}

Winning the War is Being Cured of the Disease The usage of WINNING THE WAR IS BEING CURED OF THE DISEASE conceptual metaphor like MEDICAL PROCEDURES ARE ATTACKS BY THE PATIENT conceptual metaphor, was limited in the newspapers under investigation. Some examples of this metaphor were found in Libération and La Presse de Tunisie. As in the examples in Table 7, curing COVID-19 constitutes winning a battle. In these contexts, the source domain of WAR is mapped onto the DISEASE/COVID-19 target domain. 
Table 7

Conceptual Metaphor - WINNING THE WAR IS BEING CURED OF THE DISEASE

\begin{tabular}{|c|c|c|}
\hline $\begin{array}{l}\text { Conceptual } \\
\text { Metaphor }\end{array}$ & Examples & English Translation \\
\hline $\begin{array}{l}\text { WINNING THE } \\
\text { WAR IS BEING } \\
\text { CURED OF THE } \\
\text { DISEASE }\end{array}$ & $\begin{array}{l}\text { (1) Vaincre la pandémie de coronavirus serait } \\
\text { la vraie victoire de la saison... (Libération) } \\
\text { (2) Vaincre cette pandémie exige "l'effort de } \\
\text { santé publique le plus massif de } \\
\text { l'histoire"... (La Presse de Tunisie) }\end{array}$ & $\begin{array}{l}\text { Beating the coronavirus pandemic would be } \\
\text { the real victory of the season... } \\
\text { Defeating this pandemic requires "the most } \\
\text { massive public health effort in history" ... }\end{array}$ \\
\hline
\end{tabular}

\section{Being Defeated is Dying}

Being healed is winning a war, so being defeated is dying. While some infected people get cured and survive the infection, others give up and die. As

Table 8

BEING DEFEATED IS DYING

\begin{tabular}{|c|c|c|}
\hline $\begin{array}{l}\text { Conceptual } \\
\text { Metaphor }\end{array}$ & Examples & English Translation \\
\hline $\begin{array}{l}\text { WINNING THE } \\
\text { WAR IS BEING } \\
\text { CURED OF THE } \\
\text { DISEASE }\end{array}$ & $\begin{array}{l}\text { (1) Vaincre la pandémie de coronavirus serait } \\
\text { la vraie victoire de la saison... (Libération) } \\
\text { (2) Vaincre cette pandémie exige "l'effort de } \\
\text { santé publique le plus massif de } \\
\text { l'histoire"... (La Presse de Tunisie) }\end{array}$ & $\begin{array}{l}\text { Beating the coronavirus pandemic would be } \\
\text { the real victory of the season... } \\
\text { Defeating this pandemic requires "the most } \\
\text { massive public health effort in history" ... }\end{array}$ \\
\hline
\end{tabular}

\section{Disease is a Disaster}

The second most prototypical source domain employed to describe COVID-19 is DISASTER. The DISEASE IS A DISASTER conceptual metaphor is multifaceted as it can be a mapping from the source domain that is a natural disaster, a human-made disaster, or a combination of the two. In the selected newspapers, all these types of shown in the examples in Table 8 , the victims passed away after their body's resistance against COVID-19 stopped. metaphorical mapping were employed. However, DISEASE IS A NATURAL DISASTER conceptual metaphor was dominant. For instance, in Example (1) in Table 9, COVID-19 is conceptualized as a wave, and thus a natural phenomenon. For another instance, Example (2) portrays a metaphor that maps the source domain of TSUNAMI onto the target domain of DISEASE.

Table 9

DISEASE IS A NATURAL DISASTER

Conceptual

Metaphor

Disease Is A

NATURAL

DISASTER

\section{Examples}

(1) Les autorités craignent une deuxième vague de contaminations liée aux cas importés de l'étranger. (Libération)

(2) ...Londres est confrontée à un «tsunami » de malades gravement atteints dans ses hôpitaux... (La Presse de Tunisie)
Metaphorical mappings from a combination of natural and human-made disasters were limited. For example, COVID19 and police violence, in Example (1) in Table 10, are designated as dangerous pandemics. What is interesting about this example is that police violence is comprehended in terms of a disease, compared with the above-mentioned examples in which disease is understood in terms of violence, notably attack. The use of the coordinates COVID-19 and police violence implies a mixture of natural and human-made danger. In Example (2) in Table 10, COVID-19, the currently unstoppable disaster is contrasted with the educational institutions' vulnerable situation (caused by humans).

Conceptualizing COVID-19 in terms of human-made disaster was very limited in the newspapers under investigation. For instance, Example (3) below suggests that the birthplace of
COVID 19 was Wuhan, implying that the virus began and developed in Wuhan. Thus, humans made this biological disaster. In this example, the conceptualization of disease as a human-made disaster may overlap with its conceptualization as an 'instrument of war', to use O'Reilly's (2010) expression. In this image, cradle's most typical elements evoked are birthplace, nurture, and parent, suggesting that the (local) parent created the virus. COVID-19 is viewed as a biological weapon made by humans in a more direct context as Example (4) shows. In this instance, the virus is conceptualized as a weapon, that is, a weapon of cold war. More importantly, conceptualizing the virus as a weapon does not only have political dimensions, but also economic and social dimensions. For example, a lady viewed COVID-19 as a weapon created by the powerful (government) to kill poor people, as shown in Example 5 below. 
Table 10

DISEASE IS A DISASTER

Conceptual

Metaphor

(1) ...l'Amérique est actuellement confrontée à deux dangereuses pandémies: Covid-19 et violences policières. (Libération)

(2) La crise du coronavirus, qui risque fort de se prolonger, a dénudé la situation fragile de ces établissements éducatifs. (La Presse de Tunisie)

(3) ...des experts du bureau de l'OMS en Chine avaient pu effectuer une brève visite de terrain dans la ville de Wuhan, berceau de l'épidémie. (Libération)

DISEASE IS A DisAster

(4) Un quart (26\%) des répondants, selon le sondage, croit en la véracité de la principale fausse nouvelle, soit que le coronavirus a été conçu comme une arme biologique dans un laboratoire en Chine et disséminé dans la population. (Libération)

(5) Les puissants ont diffusé le virus pour tuer les The powerful spread the virus to kill the poor... pauvres... (Libération)

\section{Disease is a Killer}

Metaphorical expressions in which COVID-19 is described to kill large numbers of people are multifarious in the newspapers under study. They are instantiations of different conceptual metaphors, namely DISEASE IS WAR, DISEASE IS A DISASTER, and DISEASE IS A KILLER. In war, the principle that reigns is to kill or to be killed. Many concordance lines in the data retrieved comprise metaphors of humans killing Coronavirus, as in nous n'avons rien encore qui puisse tuer ou arrêter le virus (we have nothing yet that can kill or stop the virus) (La Presse de Tunisie). Other concordance lines, in contrast, consist of images of the virus killing humans, as in ...nouveau coronavirus qui continue de tuer implacablement dans un monde partiellement paralysé... (the new coronavirus which continues to kill relentlessly in a partially paralyzed world) (Libération). In the same vein, many metaphorical expressions, representing DISEASE IS A DISASTER conceptual metaphor, which portray the virus's killing of people were found in the newspaper data set. A good example is ...la pandémie de nouveau coronavirus, qui a durement frappé l'Espagne... (... the novel coronavirus pandemic, which hit Spain hard ...) (Libération).

In some other instantiations, Coronavirus, on the other hand, is conceptualized in terms of a killer, evoking elements such as criminal, robber, and victim. Coronavirus is described in Example (1) in Table 11 as a ruthless criminal who steals people from their loved ones, killing them, and deprives them of a dignified farewell, with no condolences or consolation. In Example (2) in Table 11, COVID-19 is represented not only as a silent murderer, but also as an assassin who kills all. It is, in other words, an infection that is insidious.

Table 11

CORONAVIRUS IS A KILLER

\begin{tabular}{|c|c|c|}
\hline $\begin{array}{l}\text { Conceptual } \\
\text { Metaphor }\end{array}$ & Examples & English Translation \\
\hline $\begin{array}{l}\text { CORONAVIRUS IS A } \\
\text { KILLER }\end{array}$ & $\begin{array}{l}\text { L'épidémie tue deux fois : elle dérobe les } \\
\text { gens de leurs proches et les prive d'un dernier } \\
\text { adieu. (Libération) } \\
\text { Biologistes, infectiologues, pontes de la } \\
\text { médecine, chercheurs...sont médusés par la } \\
\text { force de frappe de ce virus qui tue en silence } \\
\text { sans distinction de race, de sexe et de } \\
\text { catégorie sociale. (La Presse de Tunisie) }\end{array}$ & $\begin{array}{l}\text { The epidemic kills twice: it robs people of their } \\
\text { loved ones and deprives them of a last } \\
\text { farewell. } \\
\text { Biologists, infectiologists, medical officials, } \\
\text { researchers...are astounded by the striking } \\
\text { force of this virus that kills in silence without } \\
\text { distinction of race, sex and social category. }\end{array}$ \\
\hline
\end{tabular}

The most frequent conceptual metaphors for the target domain of COVID-19 were mapped from the source domain of WAR. The subdomains of this generic source domain, namely AN ENEMY, A BATTLEGROUND, AN ATTACK BY THE DISEASE, A WEAPON, and BEING DEFEATED, were ubiquitous in all the newspapers under study. However, the subdomains of ATTACKS BY THE PATIENT and WINNING THE WAR were seldom used in the newspapers. The scarcity of metaphorical mappings from these two source domains in the selected newspapers may be because 
of the period under investigation, between the middle of March and the middle of June, three months after WHO's declaration that COVID-19 is a pandemic. It is too early to talk about defeating the virus or curing people of it, given the rapid spread of the epidemic and the lack of a vaccine or medicine.

In all the selected newspapers, the ubiquity of the generic source domain of WAR to depict the disease can also be explained by the period mentioned above following the outbreak of the disease. More particularly, the dominance of the subdomains of AN ENEMY, A BATTLEGROUND, AN ATTACK BY THE DISEASE, A WEAPON, and BEING DEFEATED, reflect the period following COVID-19 outbreak, constituting 'the peak of the emergency,' to use Wicke and Bolognesi's (2020) expression. This emergency time may also explain why one of the subdomains of WAR, included in the Master Metaphor List (Lakoff et al., 1991), THE IMMUNE SYSTEM IS A DEFENCE was not found in the citations retrieved from the newspapers under study.

The second most frequent conceptual metaphors for the target domain of COVID-19 were mapped from the source domain DISASTER. This domain is not listed in the Master Metaphor List (Lakoff et al., 1991). The subdomain of this generic source domain, NATURAL DISASTER, was dominant in all the newspapers under investigation. Rarely has the subdomain of HUMAN-MADE DISASTER been used to describe Coronavirus. This finding highlights the natural phenomenon of Coronavirus, which gives the idea that human beings are irreproachable and that they must embrace and have little to do to prevent it. The virus is ultimately created by human behaviour, both before disaster strikes and while it is managed (Jones \& Helmreich, 2020).

A less frequent source domain employed to conceptualize COVID-19 in the newspaper data set is A KILLER. This domain likewise does not appear in the Master Metaphor List. This result differs from some earlier studies which demonstrate the prevalence of this source domain in framing some plagues (e.g., Mundwiler, 2013; Wallis \& Nerlich, 2005). However, as reported earlier, all the three conceptual metaphors: DISEASE IS WAR, DISEASE IS A DISASTER, and DISEASE IS A KILLER, overlap in the killing of big numbers of humans. Besides, both the source domains of WAR and A KILLER belong to physical violence. This is corroborated by previous studies, which mentioned that despite the differences between these two categories, there are overlaps between them (e.g., Wallis \& Nerlich, 2005). Also, some earlier research proposed to replace the source domain of WAR with a more generic source domain, i.e., PHYSICAL AGGRESSION (e.g., Charteris-Black, 2004; Mundwiler, 2013).

\section{CONCLUSION}

The current article aimed mainly at defining the conceptual metaphors used in the discourse of COVID-19 in North African French-speaking newspapers, i.e., Moroccan, and Tunisian Frenchspeaking newspapers. The study's findings indicated that all the newspapers under review shared the same conceptual metaphors framing the COVID-19 pandemic, namely DISEASE IS WAR, DISEASE IS A DISASTER, and DISEASE IS A KILLER. The only distinction discovered was in the subdomains of MEDICAL PROCEDURES ARE ATTACKS BY THE PATIENT and WINNING THE WAR IS BEING CURED OF THE DISEASE as the former was found in Libération only when the latter was found in Libération and Presse de Tunisie. However, these subdomains are not supposed to be employed frequently at the onset of the pandemic outbreak, because of the rapid spread of the disease and the lack of a vaccine or medicine, as discussed earlier. The results also showed that one of the subdomains of WAR, i.e., THE IMMUNE SYSTEM IS A DEFENCE, listed in the Master Metaphor List was not activated in framing COVID-19 in the newspapers under investigation.

The findings of the present study offer further evidence that the media mostly frames COVID-19 in terms of aggression, providing a deep insight into how the media in Morocco and Tunisia conceptualizes the disease. The current study's findings that WAR is the most common source domain framing COVID-19 is in line with previous results, which showed its prevalence, especially in discourses of plagues (e.g., Flusberg et al., 2018; Sontag, 1978, 1989; Wicke \& Bolognesi, 2020; Yang, 2020). However, as previously stated, DISEASE IS WAR is not the only conceptual metaphor employed. According to the data, there were two conceptual metaphors that were not included in the Master Metaphor list, although being less prototypical: DISEASE IS A DISASTER, and DISEASE IS A KILLER.

The significance and consequences of war metaphors depend closely on how they are used and may lead to positive or negative outcomes (Flusberg et al., 2018). With severe conditions like cancer, war metaphor carries a range of symbolic interpretations that may have a serious effect both on how patients view their own condition and the way others act towards them (Helman, 2007). War metaphor overemphasizes physical and physiological concerns and overlooks psychological and social dimensions (Yang, 2020). It may panic patients, reinforce the masculine, paternalistic image of medicine, weaken patients' discursive power, overemphasize the obedience of patients to healthcare professionals, and undermine the patients' personal experiences with illness (Harrington, 2012; Reisfield \& Wilson, 2004; Yang, 2020). Despite the constant criticism levelled at framing disease in terms of WAR (e.g., 
Harrington, 2012; Reisfield \& Wilson, 2004; Sontag, 1978, 1989), it is still persistent in political discourse, medical discourse, media discourse, and even public discourse.

The attempt to liberate disease from metaphor, specifically aggression metaphors, or to replace it with literal frames, suggested by Sontag (1989), though sensible, is ineffectual for many reasons. War metaphor, depicting illness as an attacker armed with a spear or quiver, can be traced back to the Middle Ages (Montgomery, 1991, cited in Lupton, 2012), as mentioned earlier. It is critical as it relates to the need to mobilize people to fight against an emergency, sacrifice, and do whatever it takes to overcome a life threat (Chiang \& Duann, 2007; Lupton, 2012). It familiarizes individuals with illness meanings and experiences, effectively assists patients in grasping pathologies, etiologies, disease and procedures of treatment, and promotes patientcentered medical care (Harrington, 2012; Reisfield \& Wilson, 2004; Yang, 2020). Without metaphor or cross-domain mapping, how can the layperson conceive the abstract concept of a pandemic? However, attempting to employ alternative source domains to the domain of WAR may be a conscious attitude, considering the patients' social and psychological aspects. But this attempt may face many, difficulties as the war metaphors are often well established and conventional metaphors whose usage is "unconscious, automatic, and typically unnoticed" (Lakoff \& Turner, 2009, p. 80). Culturally adapted new metaphors, to substitute these conventional metaphors are usually far less frequent in disease discourse.

\section{ACKNOWLEDGEMENT}

The research in this paper is part of a research project funded by Universiti Sains Malaysia Short Term Research Grant (No. 304/PHUMANITI/6315486).

\section{REFERENCES}

Anthony, L. (2005, July). AntConc: Design and development of a freeware corpus analysis toolkit for the technical writing classroom. International Professional Communication Conference, 729-737. https://doi.org/10.1109/IPCC.2005.1494244

Anthony, L. (2017). AntFileConverter (Version 1.2.1) [Computer Software]. Waseda University. https://www.laurenceanthony.net/software

Anthony, L. (2019). AntConc (Version 3.5.8) [Computer Software]. Waseda University. https://www.laurenceanthony.net/software

Cameron, L. (2003). Metaphor in educational discourse. Continuum.
Cameron, L. (2008). Metaphor shifting in the dynamics of talk. In M. S. Zanotto, L. Cameron, \& M. C. Cavalcanti (Eds.), Pragmatics and beyond new series (pp. 45-62). John Benjamins.

Charteris-Black, J. (2004). Corpus approaches to critical metaphor analysis. Palgrave Macmillan.

Chiang, W. Y., \& Duann, R. F. (2007). Conceptual metaphors for SARS: 'War' between whom? Discourse \& society, 18(5), 579-602.

Flusberg, S. J., Matlock, T., \& Thibodeau, P. H. (2018). War metaphors in public discourse. Metaphor and Symbol, 33(1), 1-18.

Harrington, K. J. (2012). The use of metaphor in discourse about cancer: A review of the literature. Clinical Journal of Oncology Nursing, 16(4), 408.

Helman, C. (2007). Culture, health and illness ( $5^{\text {th }}$ ed.). CRC press.

International Organisation of La Francophonie. (2019). The French language worldwide 2018. Éditions Gallimard. http://observatoire. francophonie.org/wpcontent/uploads/2019/02/LFDM-SyntheseAnglais.pdf

Johnson, M. (2008). Philosophy's debt to metaphor. In R. W. Gibbs Jr, (Ed.), The Cambridge handbook of metaphor and thought (pp. 3952). Cambridge University Press.

Jones, D. S., \& Helmreich, S. (2020). The shape of epidemics. Boston Review. http://bostonreview.net/science-nature/david-sjones-stefan-helmreich-shape-epidemics.

Karlberg, M., \& Buell, L. (2005). Deconstructing the 'war of all against all': The prevalence and implications of war metaphors and other adversarial news schema in TIME, Newsweek, and Maclean's. Journal of Peace and Conflict Studies, 12(1), 22-39.

Koller, V. (2006). Of critical importance: Using electronic text corpora to study metaphor in business media discourse. In A. Stefanowitsch \& S. Th. Gries (Eds.), Corpus-based approaches to metaphor and metonymy (pp. 237-266). De Gruyter Mouton.

Kövecses, Z. (2005). Metaphor in culture: Universality and variation. Cambridge University Press.

Kövecses, Z. (2010). Metaphor: A practical introduction. Oxford University Press.

Kövecses, Z. (2015). Where metaphors come from: Reconsidering context in metaphor. Oxford University Press.

Kövecses, Z. (2018). Metaphor in media language and cognition: A perspective from conceptual metaphor theory. Lege Artis, 3(1), 124-141.

Lahlou, H. (2020). A Corpus-based cognitive linguistic analysis of pre-existing knowledge of scientific terminology: The case of English 
energy and Arabic طَاقَّة (ṭa qa). Arab World English Journal for Translation and Literary Studies, 4(1), 3-13. http://doi.org/10.24093/awejtls/vol4no1.1

Lahlou, H. (2021). Concepts in physics: A comparative cognitive analysis of Arabic and French terminologies. Institut Terjemahan \& Buku Malaysia (ITBM).

Lakoff, G., Espenson, J., \& Schwartz, A. (1991). Master metaphor list, Draft ( $2^{\text {nd }}$ ed.), Technical Report. University of California at Berkeley. https://araw. mede. uic. edu/ alansz/metaphor/METAPHORLIST. pdf.

Lakoff, G. (1993). The contemporary theory of metaphor. In Ortony, A. (Ed.), Metaphor and thought (pp. 202-251). Cambridge.

Lakoff, G., 2008. Women, fire, and dangerous things: What categories reveal about the mind. The University of Chicago Press. (Original work published 1987)

Lakoff, G., \& Johnson, M. (2008). Metaphors we live by. The University of Chicago Press. (Original work published 1980)

Lakoff, G., \& Turner, M. (2009). More than cool reason: A field guide to poetic metaphor. The University of Chicago Press. (Original work published 1989)

Lupton, D. (2012). Medicine as culture: Illness, disease and the body ( $3^{\text {rd }}$ ed.). Sage.

Mason, Z. J. (2004). CorMet: A computational, corpus-based conventional metaphor extraction system. Computational linguistics, 30(1), 2344.

Mundwiler, V. (2013). 'Catch it, bin it, kill it.' On the metaphorical conceptualisation of the 2009 swine flu pandemic in British media texts. Metaphorik. de, 24, 37-63.

O'reilly, A. (Ed.). (2010). Encyclopedia of motherhood. Sage Publications.

Reisfield, G. M., \& Wilson, G. R. (2004). Use of metaphor in the discourse on cancer. Journal of Clinical Oncology, 22(19), 4024-4027.

Sabucedo, J. M., Alzate, M., \& Hur, D. (2020). COVID-19 and the metaphor of war (COVID-
19 y la metáfora de la guerra). International Journal of Social Psychology, 35(3), 618-624. Sardinha, T. B. (2008). Metaphor probabilities in corpora. In M. S. Zanotto, L. Cameron, \& M. C. Cavalcanti (Eds.), Confronting metaphor in use: An applied linguistic approach (pp. 12748). John Benjamins.

Sardinha, T. B. (2011). Metaphor and corpus linguistics. Revista Brasileira de Linguística Aplicada, 11(2), 329-360.

Sontag, S. (1978). Illness as metaphor. Farrar, Straus and Giroux.

Sontag, S. (1989). Illness as mMetaphor and AIDS and its metaphors. Farrar Straus and Giroux.

Sun, Y., \& Li, K. (2016). A study of metaphor translation in the commentary of Shaanxi history museum from the perspective of CMT. Skase Journal of Translation and Interpretation, 9(2), 69-93.

Van der Geest, S., \& Whyte, S. R. (1989). The charm of medicines: metaphors and metonyms. Medical Anthropology Quarterly, 3(4), 345367.

Wallis, P., \& Nerlich, B. (2005). Disease metaphors in new epidemics: the UK media framing of the 2003 SARS epidemic. Social science \& medicine, 60(11), 2629-2639.

Wicke, P., \& Bolognesi, M. M. (2020). Framing COVID-19: How we conceptualize and discuss the pandemic on Twitter. PLOS ONE, 15(9), 124 .

World Health Organization. (2020, March 11). WHO Director-General's opening remarks at the media briefing on COVID-19. https://www.who.int/dg/speeches/detail/whodirector-general-s-opening-remarks-at-themedia-briefing-on-covid-19---11-march-2020

Yang, Z. (2020). Military metaphors in contemporary Chinese disease coverage: A case study of the People's Daily, 1946-2019. Chinese Journal of Communication, 14(3), 259-277. https://doi.org/10.1080/17544750.2020.181859 3 